\title{
Developing Northern California's first ranch marketing program
}

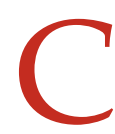

alifornia's El Dorado County was once part of a thriving commercial pear-growing region. In 1958 , its growers produced more than 52,000 tons of pears on 3,400 acres. The local Placerville Fruit Growers Association, established in 1915, was a busy pear-packing cooperative. But in the late 1950s, pear decline disease invaded California and nearly destroyed nearly all of El Dorado's premium Bartlett pear orchards. By 1964, the county's production had dropped to 8,435 tons. Farmers were devastated, and their families at risk.

The late Dick Bethell was UC Cooperative Extension pomology advisor in El Dorado, San Luis

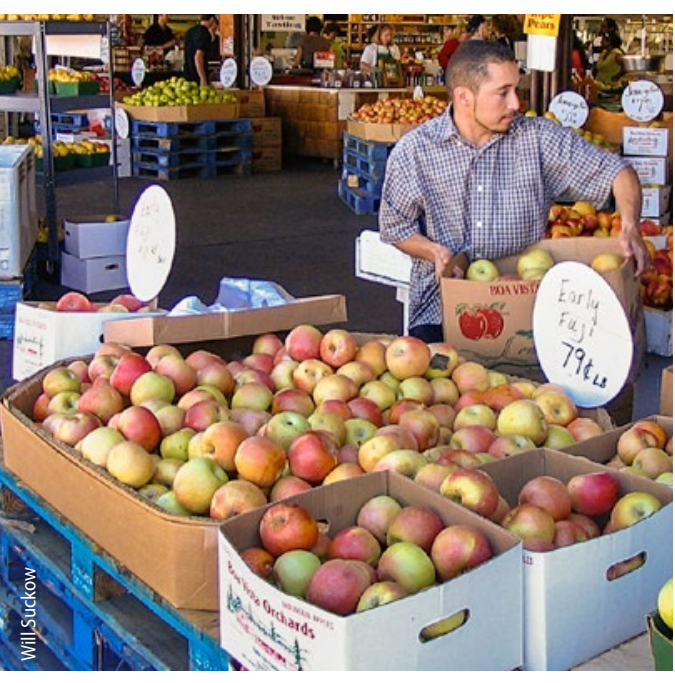

Apple Hill has the largest concentration of apple growers in all of California. Above, Boa Vista Orchard in Placerville.
Obispo, Santa Cruz and Sonoma counties but he lived in Placerville. He couldn't stand watching his community suffer, and he got to work restructuring El Dorado's entire growing industry. Bethell encouraged local growers to diversify into stone fruits, wine grapes, berries and, most of all, apples.

In the 1960s, after a visit to Oak Glen, a successful apple-growing region in Southern California's San Bernardino Mountains, Bethell and his partners envisioned a similar agritourism industry in El Dorado County, based on apple production. Bethell, grower Gene Bolster, agricultural commissioner Ed Delfino, and retired army officer Bob Tuck formed the Apple Hill Growers Association, based on the Oak Glen model and its agritourism bylaws. The following summer, in 1964, they held their first Apple Hill picnic for the news media, and not long afterwards they recruited visitors at the California State Fair.

Today, the Apple Hill Growers Association has grown from 16 farmer members to over 55 , and Apple Hill has the largest concentration of apple growers in all of California. Their efforts have paid off: Apple Hill has become a very popular tourist destination in Northern California. More than 750,000 visitors tour the area each year to visit you-pick farms; buy fresh apples and apple products; chop Christmas trees; eat lunch; and stop at a local brewery, spa and wineries.

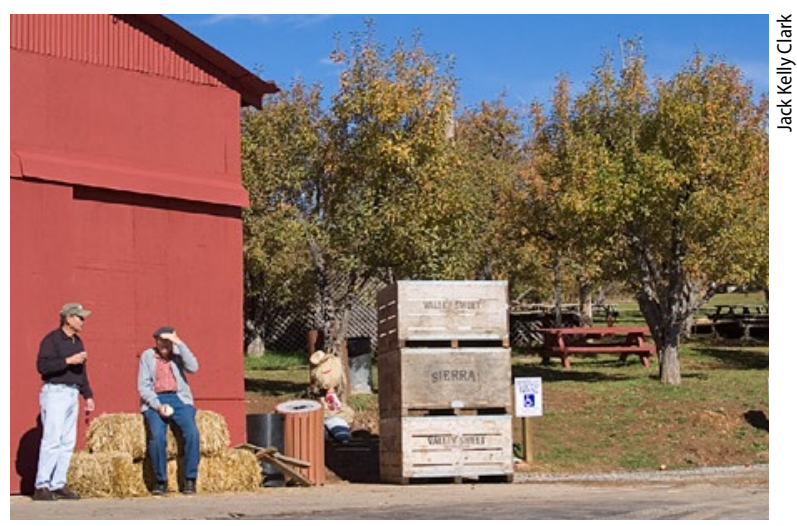

More than 750,000 visitors tour the Apple Hill area each year to buy fresh apples and apple products.

Apples aren't the only crop El Dorado visitors now enjoy, and UCCE's Bethell had a hand in that as well. Once a thriving wine country, with early settlers supplying Gold Rush communities with spirits and fruit, El Dorado's wine grape industry suffered during Prohibition and from grape phylloxera.

In 1965, Bethell oversaw the planting of several wine grape test plots at various foothill elevations in the county. The wines produced from these plots were evaluated by the UC Davis Department of Enology, which confirmed the suitability of the region for quality wine grapes. The re-emerging industry grew from 6 acres to more than 2,000 acres of vines and 50 wineries during Bethell's tenure. The county was officially designated as an American Viticultural Area in 1983, and today, thanks to the early encouragement by Dick Bethell, El Dorado produces some of California's top wines and most beloved apples.

- Marissa Palin Stein 